\title{
Intestinal Parasites and Nutritional Status in Children under 14 years of age at the Paediatric Hospital David Bernardino in Luanda, Angola
}

\author{
Parasitoses Intestinais e Estado Nutricional em Crianças dos 0 aos 14 anos de idade no \\ Hospital Pediátrico David Bernardino em Luanda, Angola
}

\author{
Marcelina Barros ${ }^{1}$, Sandra Epesse ${ }^{1}$, Joaquim Van Dunen ${ }^{2}$, Maria do Céu Costa ${ }^{1}$, Silvana Belo ${ }^{3}$ \\ ${ }^{1}$ ERISA-Escola Superior de Saúde Ribeiro Sanches, Poço do Bispo, Rua Fernando Palha, 61900-693 Lisboa \\ ${ }^{2}$ Hospital Pediátrico David Bernadino, Rua Amílcar Cabral, Maianga Luanda, Angola \\ ${ }^{3}$ Instituto de Higiene e Medicina Tropical Universidade Nova de Lisboa, Rua da Junqueira, 100 1349-008 Lisboa. \\ Email:marcelina82@live.com.pt@gmail.com
}

\begin{abstract}
This study aimed to assess the prevalence of intestinal parasitic infections in a paediatric population aged from 0 to 14 years old, hospitalized in the Paediatric Hospital David Bernardino in Luanda (HPDBL), and its association with nutritional status. The study involved 64 children admitted in the wards of "undernutrition" and "general". Detection of intestinal parasites in faecal samples was assessed by fresh examination stained with Lugol, as used at the HPDBL. The evaluation of nutritional status of children in HPDBL included clinical, biochemical and anthropometric parameters.

Out of the 64 children analyzed, six $(9.3 \%)$ were infected with Giardia lamblia (6.3\%), Ascaris lumbricoides $(1.6 \%)$ and Hymenolepis diminuta (1.6\%). These cases of parasitism were more common in children over three years and hospitalized in the general ward. Regarding nutritional status, the majority (56.3\%) had some kind of nutritional deficiency (body weight below 70\%, oedema in both legs, severe thinness), which were more frequent in females (55.6\%) and in children under 24 months (77.7\%). About 92.2\% of children admitted were from suburban areas of Luanda presenting greater vulnerability to parasitic infections and other diseases owing to households conditions, with a majority without piped water. However, no evidence has been encountered in this population sample of an association between intestinal parasites and malnutrition throughout the present study.
\end{abstract}

Keywords: Intestinal parasites, malnutrition, children, Paediatric Hospital, Luanda, Angola.

\section{RESUMO}

Este trabalho teve como objetivo avaliar a ocorrência de parasitoses intestinais numa população infantil dos 0 aos 14 anos de idade, internadas no Hospital Pediátrico David Bernardino em Luanda e a sua associação ao estado nutricional. O estudo envolveu 64 crianças internadas nas enfermarias de "subnutrição ou malnutrição" (EM) e "geral" (EG). Os métodos utilizados para a pesquisa dos parasitas intestinais nas amostras fecais, em vigor no HPDBL, foram o exame a fresco por coloração com Lugol. A avaliação do estado nutricional das crianças no HPDBL inclui parâmetros clínicos, bioquímicos e antropométricos. Das 64 crianças analisadas, detectaram-se seis crianças parasitadas, sen quatro $(6,3 \%)$ por Giardia lamblia, uma $(1,6 \%)$ por Ascaris lumbricoides e uma $(1,6 \%)$ por Hymenolepis diminuta. Estes casos de parasitismo foram mais frequentes nas crianças com mais de três anos e internadas na Enfermaria geral (EG). Cerca de 92,2\%, das crianças internadas eram provenientes de zonas suburbanas de Luanda com condições vulneráveis às infeções parasitárias e outras doenças. Contudo, não foi evidenciada, nesta amostra populacional, uma associação entre as parasitoses intestinais e a malnutrição.

Palavras-Chaves: Parasitas intestinais, malnutrição, crianças, Hospital Pediátrico, Luanda, Angola. 


\section{Introduction}

Intestinal parasites include a broad group of microorganisms, of which protozoa and helminths are the most representative. The faecal-oral is the main route of transmission, through water and /or contaminated food. The prevalence of human parasitic infections varies by geographic area and also depends on climatic and social conditions, namely safe drinking water supplies and sanitation. The rate of parasitic infections is highest in sub-Saharan Africa, followed by Asia, Latin America and the Caribbean. ${ }^{[1,2,3,4,5]}$

Malnutrition is one of the major public health problems, particularly in developing countries, and is closely linked to several factors, including deficient food intake, concurrent infections by various pathogens (bacterial, viral, parasitic), and poor social conditions. According to the World Health Organization (WHO) ${ }^{[6,7]}$ malnutrition is a multifactorial disease of clinical and social nature due to insufficient or lack of food intake and increased needs for nutrients due to intestinal malabsorption caused by certain diseases. The severe form can reach all organs of the child, becoming chronic and potentially leading to death if not treated properly and as quickly as possible. Malnutrition can begin early in the intrauterine life (low birth weight) and often in early childhood as a consequence of the interruption of exclusive breastfeeding and inappropriate complementary feeding in the first two years of life. Such food deprivation is often associated with lifelong and recurrent episodes of infectious diseases (diarrhoea, respiratory infections, parasites, etc.).

Other risk factors that may be associated with malnutrition include low socioeconomic conditions, poor knowledge of mothers about child nutrition, hygiene and general health care.

Based on the WHO guidelines ${ }^{[6,8]}$, the criteria for the classification of malnutrition include: edema in both feet (kwashiorkor, marasmic kwashiorkor), severe weight loss (marasmus) and anthropometric data, including height-weight ratio lower than $70 \%$ or lower - 3DP (or z-score), or the presence of clinical signs of severe malnutrition such as lack of adipose tissue, extreme thinness at the level of the shoulders, upper limbs, buttocks and thighs, with visible and prominent ribs. ${ }^{[9,10]}$

Several studies have shown that parasites may contribute directly to aggravate malnutrition. ${ }^{[11,12]}$ Children, especially during early childhood and in populations of lower social and economic conditions, are among the most vulnerable groups suffering from malnutrition and parasitic infections.

\section{Introdução}

Os parasitas intestinais incluem um amplo grupo de microrganismos, dos quais os protozoários e os helmintas são os mais representativos. As águas e/ou alimentos contaminados são as fontes de infeção mais frequentes sendo a via fecal-oral a principal via de transmissão. A sua prevalência varia consoante a zona geográfica, dependendo também das condições higieno-sanitárias e climatéricas. A taxa de infecção é máxima na África Subsariana, seguida da Ásia, América Latina e Caribe. $[1,2,3,4,5]$.

A malnutrição é um importante problema de saúde pública, particularmente nos países em vias de desenvolvimento, estando estreitamente associada a diversos factores, dos quais se destacam as deficiências alimentares, a ocorrência simultânea de infecções por diversos agentes patogénicos, tanto bacterianos como parasitários e deficientes condições de saneamento básico. Segundo a Organização Mundial de Saúde (OMS) ${ }^{[6]}$, a malnutrição é uma doença de natureza clínico-social multifatorial que resulta de um défice de ingestão alimentar, necessidades aumentadas de nutrientes no organismo por má absorção intestinal (por doença) ou devido ao fornecimento alimentar insuficiente (carência de meios ou perda de apetite). A forma grave pode atingir todos os órgãos da criança, tornando-se crónica e levando ao óbito, caso não seja tratada adequadamente e o mais rápido possível. Pode começar precocemente na vida intra-uterina (baixo peso ao nascer) e frequentemente cedo na infância, na sequência da interrupção precoce do aleitamento materno exclusivo e da alimentação complementar inadequada nos primeiros dois anos de vida, associada, muitas vezes, à privação alimentar ao longo da vida e à ocorrência de repetidos episódios de doenças infeciosas (diarreias, infeções respiratórias, parasitismo, entre outras). ${ }^{7}$

Outros fatores de risco que podem estar associados à malnutrição incluem as baixas condições socioeconómicas, precário conhecimento das mães sobre os cuidados com a criança pequena relativamente à alimentação, higiene e cuidados com a saúde de modo geral.

De acordo com a OMS ${ }^{[6,8]}$, os critérios para a classificação de malnutrição incluem: presença de edema em ambos os pés (Kwashiorkor, Kwashiorkor marasmático), emagrecimento grave (Marasmo), sendo os critérios para sua avaliação definidos por dados analíticos, antropométricos, nomeadamente a relação peso-altura menor de $70 \%$ ou menor de - 3DP (ou z-score) Ou ainda pela presença de sinais clínicos de malnutrição grave, incluindo ausência de tecido adiposo, magreza extrema a nível dos ombros, membros superiores, náde- 
In Angola, according to the Ministry of Health of Angola (MINSA), the prevalence of both health conditions are still high and, as reported by the World Health Organization (WHO), ${ }^{[13,]}$ over 2.4 billion people (one third of the world population), will be kept without access to basic sanitation by 2015. Thus, the goal of achievement the 2015 Millennium Development Goals (MDGs) to reduce by half the proportion of people without sanitation will not be met. ${ }^{[13,14,15]}$

In Angola, most of the health infrastructures were destroyed during the long period of civil war, and according to the UNDP indicators, over $68 \%$ of Angolan people live under the poverty rate, with $26 \%$ living in extreme poverty with less than a USD per day ${ }^{[16]} \mathrm{Al}$ though the Government of Angola (GoA) is engaged in reconstruction and development, creating infrastructure for the provision of basic health and social services, the current situation remains highly deficient in many regional settings.

Inadequate access and insufficient supply of safe drinking water and sanitation services for the majority of the Angolan population still have serious repercussions, especially in children. Every day one child in four dies of diarrhoea or other diseases (including parasite infections) related to water and sanitation in Angola. The burden of diseases are particularly heavy in rural areas, where about $71 \%$ of the households have no access to safe water and $79 \%$ do not have adequate sanitation at home, therefore excreta are deposited in the soil with consequent environmental contamination.

This study aimed to assess the frequency of intestinal parasites and their relationship with malnutrition in children aged less than 14 years, hospitalized in the Paediatric Hospital in Luanda.

\section{Materials and Methods}

The study was conducted in a group of children aged from $0-14$ years of age (target population), admitted in the general and nutrition wards at the paediatric hospital David Bernardino (HPDB) in Luanda during September 2013. For parasitological examination, a stool sample was requested from each child. Faecal samples gas e coxas, com costelas visíveis e salientes ${ }^{[9,10]}$. Vários estudos demonstram que as parasitoses contribuem diretamente para o seu agravamento ${ }^{[11,12]}$. De entre os grupos mais vulneráveis à ocorrência de parasitoses e subnutrição, encontram-se as crianças, da primeira infância pertencentes às comunidades mais desfavorecidas social e economicamente. Em Angola, segundo o Ministério de Saúde de Angola (MINSA), a prevalência de infeções parasitárias permanece elevada.

De acordo com um relatório da Organização Mundial de Saúde (OMS) ${ }^{[13]}$, cerca de 2,4 mil milhões de pessoas (um terço da população mundial), ficarão sem acesso a saneamento básico em 2015. No ritmo actual, a meta dos Objetivos de Desenvolvimento do Milénio para 2015 (ODM) em reduzir para metade a proporção da população sem saneamento não será atingida. ${ }^{[14,15]}$

Em relação a Angola, o longo período de guerra civil deixou as infra-estruturas sanitárias locais e nacionais em ruínas. Segundo os indicadores do Programa das Nações Unidas para o Desenvolvimento (PNUD), 68\% dos Angolanos vivem actualmente abaixo do limiar da pobreza, com $26 \%$ vivendo em pobreza extrema, sobrevivendo com menos de um dólar por dia ${ }^{[16]}$. No entanto, o Governo de Angola (GdA) está empenhado na reconstrução e no desenvolvimento, criando infra-estruturas para a prestação de serviços básicos.

$\mathrm{O}$ acesso inadequado e a insuficiente distribuição de água potável e de serviços de saneamento para a maioria da população Angolana continuam a ter graves repercussões, especialmente nas crianças. Todos os dias uma criança em cada quatro morre de diarreia ou de outras doenças (incluindo as parasitoses intestinais) relacionadas com a água e falta de saneamento. As repercussões são particularmente pesados nas zonas rurais, onde cerca de $71 \%$ dos agregados familiares não tem acesso a água potável em casa e 79\% não tem equipamentos e saneamento adequados, recorrendo a coleções hídricas para abastecimento de água e utilizando o meio ambiente para deposição dos excreta.

Este estudo teve como objetivo avaliar a frequência de parasitas intestinais e a sua relação com a malnutrição, em crianças dos 0 aos 14 anos internadas no Hospital Pediátrico David Bernardino em Luanda.

\section{Materiais e Métodos}

$\mathrm{O}$ estudo foi realizado num grupo de crianças dos 0 a 14 anos de idade (população alvo), internadas nas Enfermarias geral e de nutrição do HPDB no período em que decorreu o estudo (setembro 2013). Em cada caso foi solicitada uma amostra de fezes para o exame parasitológico, pela técnica de exame a fresco, usada na 
were analyzed by direct saline and iodine wet mount under microscopy, the only parasitolical method used in the hospital. In special cases, a commercial kit was employed for detection Giardia antigen.

Some additional information regarding biochemical and current anthropometric data were obtained from the clinical records of children. To obtain data on food habits, house conditions, and the education level of mothers or child's legal representative, we applied a questionnaire based on interview of children's relatives. The survey used to evaluate food intake was previously validated within this study. It was piloted on a few of voluntaires and showed to have (i) simplicity and viability (ii) reliability and precision in the words (iii) to be adequate for the problem intended to measure (iv) and reflect underlying concepts to be measured. Data were entered into a database Excel program (Microsoft). For statistical analysis, the Statistical Package for Social Sciences (SPSS) version 22.0 for Windows was used. The Pearson Chi-square $\left(\chi^{2}\right)$ was applied to test frequencies of malnutrition scores, parasite infections and differences in housing conditions among the households of the two groups of children hospitalized.

\section{Results}

\section{Children data}

Out of the 64 children observed during the study period, $36(56.3 \%)$ were admitted to the malnutrition ward (MW) and 28 (43.7\%) in the general ward (GW). Although the number of children hospitalized were similar in both sexes (32), most children admitted to the MW were female $(20,55.6 \%)$ and $16(44.4 \%)$ were males, while the contrary was observed in the general ward (GW), with 16 (57.1\%) males and 12 (42.9\%) females The ages ranged from two months to 11 years (mean 32.53 months); however, the largest number of children was less than 48 months of age (Figure 1).

\section{Residence of the children}

The majority of the surveyed population (59; 92.2\%) was from the province of Luanda and only five were residents in other provinces. Most children resided in the suburban area of the city of Luanda, distributed across 18 municipalities. rotina do HPDB, embora em casos especiais executem a deteção do antigénio de Giardia através do kit comercial específico. A colheita de fezes e respectivas análises seguiram os protocolos internacionais padronizados e bem estabelecidos.

Algumas informações complementares relativas aos dados analíticos e antropométricos comuns foram obtidos das fichas das respetivas crianças. Para avaliação das condições habitacionais, alimentares e grau de escolaridade, procedemos à realização de um inquérito, por entrevista, às mães ou acompanhantes das crianças. $\mathrm{O}$ inquérito utilizado para avaliar a ingestão alimentar foi validadoneste estudo. Concretamente, foi ensaiado em alguns voluntários e mostrou ter (i) simplicidade e viabilidade (ii) confiabilidade e precisão nas palavras (iii), além de ser adequado para o problema a medir (iv) e refletir os conceitos subjacentes a serem medidos. Os dados obtidos foram inseridos numa base de dados do programa Excel (Microsoft) e sujeitos a análise estatística dos resultados utilizando-se o programa Statistical Package for the Social Sciences (SPSS) versão 22.0 para Windows. Foram aplicados os testes de Qui-Quadrado $\left(\chi^{2}\right)$ de Pearson para avaliar as frequências e as diferenças das condições habitacionais entre os agregados familiares dos dois grupos de crianças hospitalizadas.

\section{Resultados}

\section{Características da população infantil observada}

Das 64 crianças observadas durante o período do estudo, $36(56,3 \%)$ estavam internadas na Enfermaria de malnutrição (EM) e 28 (43,7\%) na EG. Apesar do número de internados ser idêntico nos dois sexos (32), a maioria das crianças da EM era do sexo feminino (20; $55,6 \%)$, sendo $16(44,4 \%)$ do sexo masculino. Contudo, verificou-se o contrário na Enfermaria geral (EG), com $16(57,1 \%)$ do sexo masculino e $12(42,9 \%)$ do sexo feminino.

As idades variaram dos dois meses aos 11 anos (média 32,53 meses), sendo o maior número de crianças do grupo etário inferior aos 48 meses (Figura 1).

\section{Origem e residência da população analisada}

$\mathrm{Na}$ população analisada,59 $(92,2 \%)$ era originária da província de Luanda e apenas cinco eram naturais e residentes noutras províncias. A maioria residia na área suburbana da cidade de Luanda, distribuída por 18 bairros. 


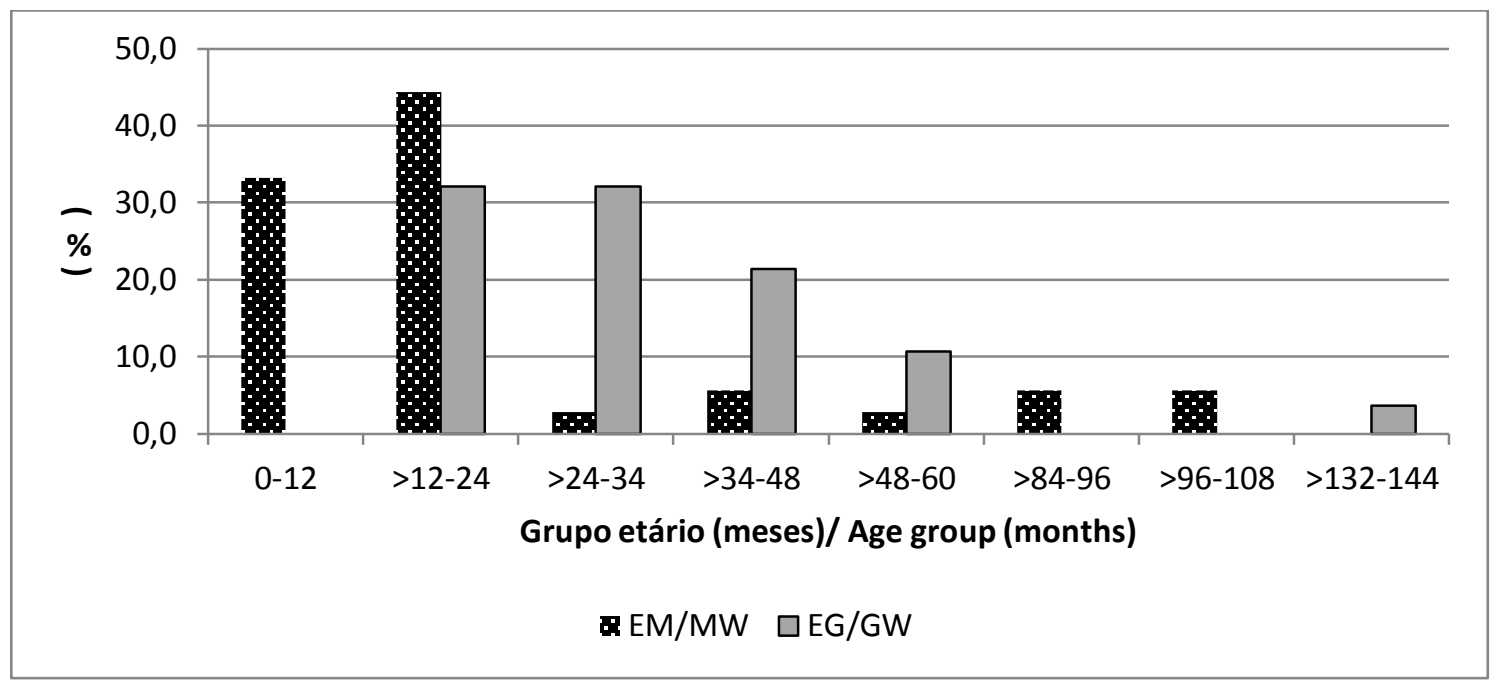

Figure 1/ Figura 1. Children hospitalized by age group (months) by ward (of malnutrition- MW and general- GW). \% versus Age group (months)

Crianças internadas por Enfermaria (de subutrição/malnutrição- EM e geral- EG) segundo o grupo etário (meses)

\section{Frequency of intestinal parasites}

Intestinal parasites were found in six faecal samples, with the protozoan G. lamblia the most frequently detected (four cases) and two cases positive for A. lumbricoides and $H$. diminuta helminths. Most of the infected children (five) were in the general ward and only one parasitized by $A$. lumbricoides was in the MW. Parasites were more frequent in female children (four) and in those older than 36 months.

\section{Nutritional status}

The presence of at least one of the parameters of nutritional status [haemoglobin $(\mathrm{Hb})$ below normal rate, weight/age (z-score) rate, oedema in both feet/ankles] in children examined at entrance was conditional for admission to the malnutrition ward (MW).

During the period of this study, 36 were children were or had been admitted to the MW and were still hospitalized at the end of the study. Complete biochemical and anthropometric data were only been obtained from 26 children (Table 1). Of these, six had severe anaemia $(\mathrm{Hb}<6 \mathrm{~g} / \mathrm{dl}), 10$ had moderate anaemia (6.1 to $10.9 \mathrm{~g} / \mathrm{dl}$ ) and only two were had normal $\mathrm{Hb}$ levels $(\geq 11 \mathrm{~g} / \mathrm{dl})$. The age group with the most serious malnutrition scores was that under 24 months. The majority $(65.4 \%)$ of these children were severely underweight $(<-3$ $z$-score), six cases presented moderate thinness (between -3 and $-2 \mathrm{z}$-score), and only three children had a normal index $(\geq-2$ z-score)

\section{Frequência de parasitas intestinais}

Foram encontrados parasitas intestinais em seis amostras fecais, sendo o protozoário G. lamblia o mais frequente (quatro casos) e dois casos positivos para helmintas A. lumbricoides e $H$. diminuta. A maioria das crianças parasitadas (cinco) estava internada na EG e apenas uma, parasitada por A. lumbricoides, estava na ES. Das seis crianças parasitadas, quatro eram do sexo feminino. Por sua vez eram as crianças com mais de 36 meses as que apresentaram mais casos (quatro casos) de parasitismo.

\section{Estado nutricional}

A presença de, pelo menos, um dos parâmetros do estado nutricional [níveis de hemoglobina $(\mathrm{Hb})$ abaixo do normal, índice de peso/idade (z-score), edema nos dois pés/tornozelos] nas crianças examinadas na urgência ou consulta pediátrica do Hospital era condição para o seu internamento na EM. Durante o tempo que decorreu o presente estudo, 36 crianças estavam e/ou foram internadas na referida Enfermaria e a maioria ainda permanecia internada no final do estudo. Destas crianças, apenas de 26 foi possível obter dados bioquímicos e antropométricos completos (Tabela 1). Destas, seis tinham anemia grave $(\mathrm{Hb}<6 \mathrm{~g} / \mathrm{dl}), 10$ tinham anemia moderada $(6,1-10,9 \mathrm{~g} / \mathrm{dl})$ e apenas duas estavam com níveis de $\mathrm{Hb}$ normal $(\geq 11 \mathrm{~g} / \mathrm{dl})$. O grupo etário com indicadores de malnutrição mais graves era o dos lactentes e menores de 24 meses. A maioria $(65,4 \%)$ destas crianças apresentava magreza acentuada ( $<-3 z$-score), seis casos com grau de magreza moderado (entre -3 e $-2 z$-score) e apenas três crianças tinham um índice normal ( $\geq-2 z$-score).

Condições habitacionais do agregado familiar das 
Table 1/ Table 1. Biochemical, anthropometric and clinical parameters of 26 children/ Parâmetros bioquímicos, antropométricos e clínicos de 26 crianças

\begin{tabular}{|c|c|c|c|c|c|c|c|}
\hline \multicolumn{3}{|c|}{$\begin{array}{l}\text { Hemoglobin/ } \\
\text { Hemoglobina }\end{array}$} & \multicolumn{3}{|c|}{$\begin{array}{c}\text { Weight / Age } \\
\text { Peso/ idade }\end{array}$} & \multicolumn{2}{|c|}{$\begin{array}{c}\text { Oedema/ } \\
\text { Edema }\end{array}$} \\
\hline Severe & Moderate & Normal & Severe & Moderate & Normal & Present & Absent \\
\hline Grave & Moderada & Normal & Grave & Moderada & Normal & Presente & Ausente \\
\hline 6 & 18 & 2 & 17 & 6 & 3 & 9 & 17 \\
\hline$(23,1 \%)$ & $(69,2 \%)$ & $(7,7 \%)$ & $(65,4 \%)$ & $(23,1 \%)$ & $(11,5 \%)$ & $(34,6 \%)$ & $(65,4 \%)$ \\
\hline
\end{tabular}

\section{Household conditions of the children}

House sanitation conditions were generally insufficient or absent; the majority did not have piped water $(73.4 \%)$ or itoilet facilities $(70.3 \%)$ (Table 2$)$. For water supply, families need to collect from neighbouring water bodies, including tanks $(31.3 \%)$, rivers $(4.7 \%)$ and fountains $(3.1 \%)$. The remaining $39(60.9 \%)$ did not report the source of water collection.

All cases of parasitic infection resided in households without piped water and the two children infected by intestinal helminths $A$. lumbricoides and $H$. diminuta also did not have a toilet in the house. crianças internadas

As condições de saneamento básico na habitação eram de um modo geral muito deficientes; a maioria $(73,4 \%)$ não dispunha de água canalizada nem de casa de banho $(70,3 \%)$ dentro da habitação (Tabela 2). Para o abastecimento de água, as famílias recorriam aos cursos de água existentes nos locais, nomeadamente tanques $(31,3 \%)$, rio $(4,7 \%)$ e chafariz $(3,1 \%)$. As restantes 39 $(60,9 \%)$ não referiram a fonte de coleta de água.

Todos os casos de infeção parasitária residiam em habitações sem água canalizada e nas duas crianças parasitadas por helmintas intestinais, A. lumbricoides e $H$. diminuta, também não dispunham de casa de banho na habitação.

Table 2/ Tabela 2. Basic sanitary conditions in children homes

Condições de saneamento básico nas habitações das crianças

\begin{tabular}{lcccc}
\hline & $\begin{array}{c}\text { Piped water/ } \\
\text { Água canalizada }\end{array}$ & \multicolumn{2}{c}{$\begin{array}{l}\text { Bathroom/ } \\
\text { Casa de banho }\end{array}$} \\
\hline Yes/ Sim & 17 & $26,6 \%$ & 19 & $29,7 \%$ \\
Not/ Não & 47 & $73,4 \%$ & 45 & $70,3 \%$ \\
\hline
\end{tabular}


Level of education of mothers or children relatives

Regarding the level of education of mothers or relatives of the hospitalized children, all were literate with minimum of two to 11 years of schooling (Figure 2).
Escolaridade das mães ou acompanhantes das crianças

Em relação ao nível de escolaridade das mães ou acompanhantes e responsáveis pela criança internada, todas eram alfabetizadas com o mínimo de dois a onze anos de escolaridade (Figura 2).

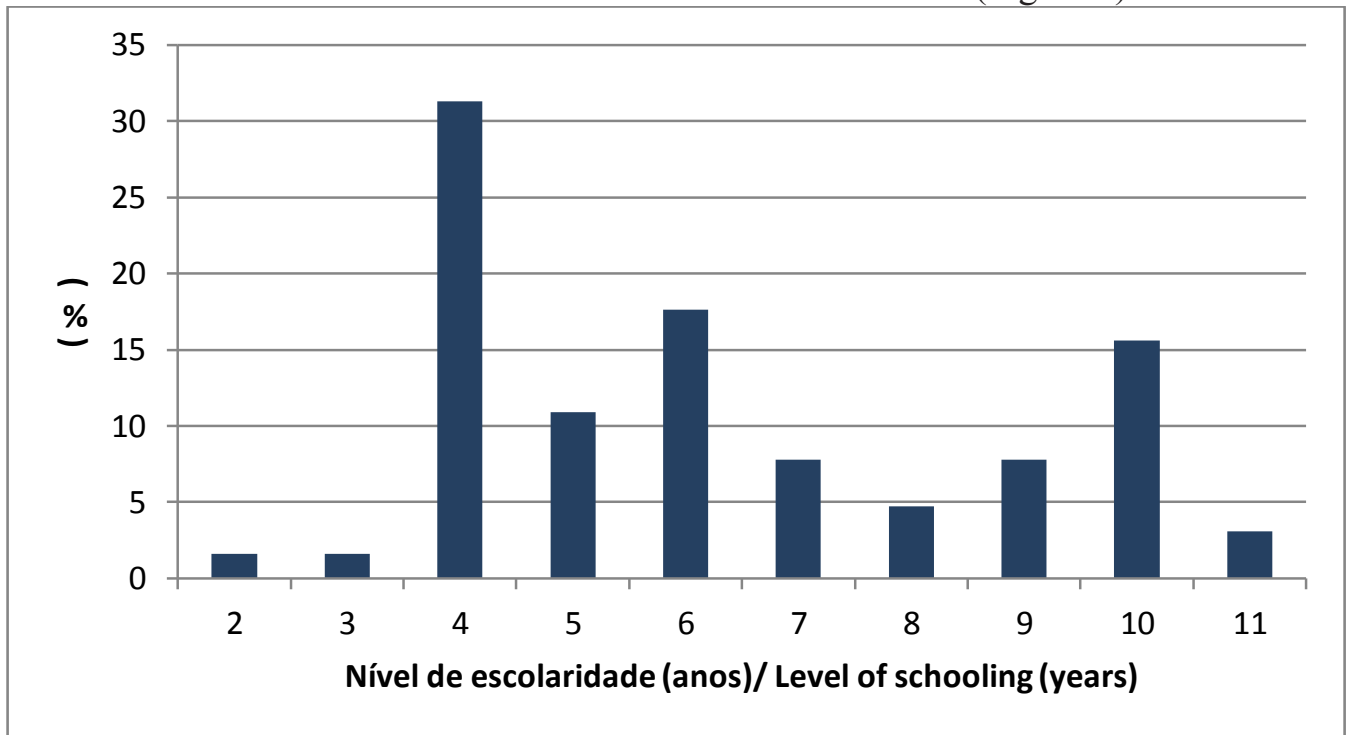

Figure 2/ Figura 2. Level of education of the mothers or guardians of children (\% versus level of schooling (years))

Nível de escolaridade das mães ou responsáveis pelas crianças

\section{Nutritional and food habits}

Most of the mothers or children's relatives' interviewed reported the consumption of essential foods used in the traditional diet (Figure 3), however food was not provided regularly due to low economic status.

\section{Alimentação do agregado familiar}

A maioria das mães ou responsáveis inquiridas referiu o consumo dos alimentos essenciais utilizados na dieta tradicional (Figura 3). No entanto, salientaram a dificuldade de o providenciar de forma regular ao seu agregado familiar.

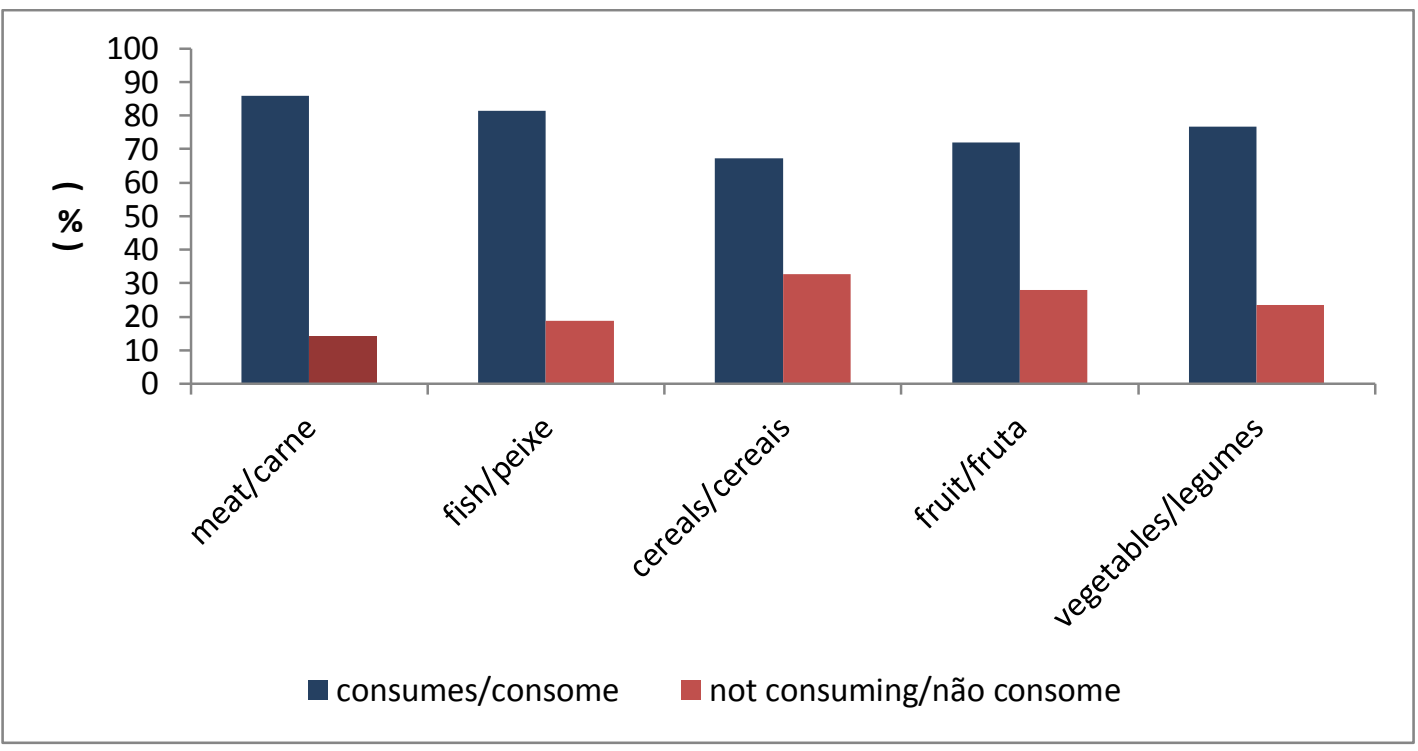

Figure 3/ Figura 3. Diet food in the household (\% versus uses / does not consume) Dieta alimentar do agregado familiar. 


\section{Discussion}

In this study, analyses of faecal samples were obtained from 64 children admitted to the Paediatric Hospital Luís Bernardino in Luanda, of which 36 were in the malnutrition ward (MW) and the remaining 28 in the general ward (GW).

We found more cases of intestinal parasites in the general ward than in the malnourished ward, likely because these patients (malnourished) were already in treatment and eventually submitted to antiparasitic therapy. However, the biochemical and anthropometric parameters of these children showed that the majority suffered from severe or moderate anaemia and malnutrition (Table $1)$, especially in the age group of infants and children under 24 months. Indeed, among the 36 malnourished children, six had haemoglobin values below the normal level (anaemia), 17 had severe weight/age ratio and nine children had severe feet oedema. Giardia lamblia, A. lumbricoides and $H$. diminuta were the intestinal parasites found in six children

In these patients, parasitological tests other than saline wet mounts are not routinely used in the hospital. However in children admitted to the general ward, detection of Giardia antigen using commercial kits was occasionally performed in faecal samples. It is likely that the low frequency of parasites found could be due to the low sensitivity of the parasitological test used. Other techniques should be employed, especially faecal concentration methods recommended for intestinal parasites, in order to improve the parasitological diagnosis. ${ }^{[17,18]}$

Considering the high prevalence of intestinal helminths in the country ${ }^{[19,20]}$, the results obtained in this study may not reflect the parasitological status of these children. Moreover, the limited number of positive faecal samples detected in this group is insufficient to found a potential association between intestinal parasites and malnutrition.

As reported by other authors ${ }^{[19,20,21,22]}$, intestinal parasites were normally distributed in both sexes and target especially children over 36 months since it is at this stage that children begin to have more direct contact with soil and generally take almost everything into the mouth.

Concerning the sociodemographic status of these children, over $92.2 \%$ resided in the suburban areas of Luanda where the socioeconomic, educational and sanitary conditions of population are worse, (Fig. 2 and Table 2) therefore most vulnerable to parasitic infections and other diseases.

\section{Discussão}

Constatou-se que na enfermaria geral (EG) houve mais casos de parasitoses intestinais relativamente à Enfermaria de malnutridos, provavelmente por esses doentes (malnutridos) já estarem em tratamento e, eventualmente, com uma terapêutica antiparasitária. No entanto, os parâmetros bioquímicos e antropométricos destas crianças demonstraram que a maioria sofria de anemia grave ou moderada e de malnutrição (Tabela 3 ), sobretudo no grupo etário dos lactentes e menores de 24 meses. Com efeito, das 36 crianças mal nutridas, seis apresentaram valores de hemoglobina abaixo do normal (anemia), 17 tinham uma relação de peso/idade grave e nove crianças apresentavam edema.

Nestes doentes, não é da rotina do hospital fazer exames para detectar parasitas intestinais por outras técnicas e quando efectuado, consiste apenas no exame directo. Já nos doentes da EG que padeciam de outras doenças, para além de se efectuar o exame direto também se fazia, por vezes, a deteção do antigénio da Giardia por meio de kit comercial. É provável que a baixa frequência de parasitas encontrados seja devida ao facto de não se efetuarem outras técnicas parasitológicas, especialmente as de concentração de fezes, indicadas para o diagnóstico das parasitoses intestinais. ${ }^{[17,18]}$.

Atendendo à elevada prevalência de helmintoses intestinais no país ${ }^{[1,20]}$, os resultados obtidos neste estudo podem não refletir o estado parasitológico destas crianças.

Apesar do número restrito de amostras fecais positivas, não parece haver, nesta amostra populacional, uma associação entre as parasitoses intestinais e a malnutrição. Assim como outros autores também reportaram [19,20,21,22] as parasitoses intestinais estavam distribuídas numa proporção equilibrada relativamente ao género, abrangendo sobretudo a faixa etária superior aos 36 meses, uma vez que é nesta fase do crescimento que as crianças começam a ter maior contacto com o solo nas suas atividades recreativas.

Relativamente à distribuição geográfica das crianças, cerca de 92,2\%, eram provenientes de zonas suburbanas de Luanda (Figura. 7), onde as condições socioeconómicas, educacionais e sanitárias dessas populações são bastante precárias (Figura. 8 e Tabela 4), confirmando a situação mais vulnerável destas populações às infeções parasitárias e outras doenças. 


\section{Conclusions}

Bearing in mind the recommendations of the World Health Organization (WHO) to consider that malnutrition is a multifactorial disease of clinical and social nature due to insufficient requirements or lack of food intake and increase nutrients due to poor intestinal absorption caused by certain diseases, parasites in hospitalized children from needy populations were surveyed. The majority of malnourished and/or parasited children inhabited in suburban areas of Luanda, in more deprived social communities without piped water and/ or house sanitation, as part of numerous families .

However, in this population sample no evidence has been encountered of an association between intestinal parasites and malnutrition and further studies are needed to better understand the specific nature of the relationship.

\section{Acknowledgments}

The authors acknowledge to the Paediatric Hospital David Bernardino in Luanda for their assistance.

\section{Conflicts of interests}

The authors declare that there are no financial or personal relationships that could be viewed as potential conflict of interests.

\section{Conclusões}

Tendo presente as recomendações da Organização Mundial da Saúde (OMS) onde se considera que a desnutrição é uma doença multifatorial de natureza clínica e social devido a necessidades insuficientes ou falta de ingestão de alimentos, e aumento de nutrientes devido à má absorção intestinal causada por certas doenças, foram pesquisadas parasitoses em crianças internadas provenientes de populações carenciadas.

A maioria das crianças desnutridas e / ou parasitadas habitavam nas áreas suburbanas de Luanda, em comunidades sociais com maiores carências de infraestruturas de saneamento, sem água e / ou sem água canalizada em casa, e em famílias numerosas. Contudo, não foi encontrada, nesta amostra populacional, evidência de uma associação entre as parasitoses intestinais e a malnutrição, sendo necessários mais estudos para melhor entender esta tão comummente referida relação.

\section{Agradecimentos}

Ao Hospital Pediátrico David Bernardino em Luanda pela colaboração na realização deste estudo.

\section{Conflitos de Interesse}

Os autores declaram que não existem relações financeiras ou pessoais suscetíveis de serem vistas como potenciais conflitos de interesse. 


\section{References/ Referências}

1. Kasper DL, Fauci AS, Longo, DL et al. Harrison - Internal Medicine. 16th ed. Rio de Janeiro: McGraw-Hill; 2011.

2. Washington Jr, William J, Elmer K et al. Microbiological Diagnosis, Text and Color Atlas.6th ed. Rio de Janeiro: SA Koogan Guanabara; 2008.

3. Rey L. Bases de Parasitologia Médica. 3rd ed., Rio de Janeiro: SA Koooogan Guanabara; 2010

4. Solaymani-Mohammadi, S., Genkinger JM, Loffredo CA et al. Meta-analysis of the Effectiveness of Albendazole Compared with Metronidazole the Treatments for Infections with Giardia duodenalis. PLoS Negl Trop Dis 2010; 4(5):e682.

5. Behrman RE, Kliegman RM, Jenson $\mathrm{HB}$ et al. Tratado de Peditria. ed 16. Rio de Janeiro: Koogan SA Guanabara; 2002.

6. WHO. Manual management of children with severe malnutrition in hospitals. Brasilia; 2005.

7. Razzolini MTP, Günther WMR, Health Impacts Due to Deficient Water Access, São Paulo: Saúde Soc.;2008: v.17, n.1. p.21-32,.

8 Correia A, Levy C C. et al. Protocol de Emergência em Pediatria. 3rd ed, ACSM publisher; 2011

9 WHO. Consultation to Develop a Strategy to Estimate the Global Burden of Foodborne Diseases. Geneva; 2006.
10. Balconies L,R, Schindler L et al. Bernadino Hospital Care for Children: Guidelines for the Management of Common Diseases with Limited Resources, 1st ed, , Lisbon: Calouste Gulbenkian Foundation;2006.

11. Ajanga A, Lwambo, NJS, Blair L et al. Schistosoma mansoni in pregnancy and associations with anemia in northwest Tanzania. Trans R Soc Trop Med Hyg 2006; 59-63.

12. Mbuh JV, Nembutsu-Ji NE. Malnutrition and intestinal helminth infections in schoolchildren from Dibanda, Cameroon. J Helminthol 2013;46-51.

13. MINSA. National Survey on the prevalence of intestinal helminths and schistosomíases in schoolchildren, Angola:MoH/MoE/WFP/ WHO/UNICEF: October-November; 2005.

14.Verhagen LM, Incani RN, Franco CR, et al. High malnutrition rate in Venezuelan Yanomami compared to Warao Amerindians and Creoles: significant associations with intestinal parasites and anemia. PLoS One 2013; 8(10):e77581.

15. Oliveira, D. Prevalence of intestinal parasites in children attending primary school in the neighborhood Lucrezia, in Lubango, Angola, and its relationship with nutritional status and anemia. Master Thesis in Tropical Health, IHMT, UNL; 2012.
16. UNDP - Angola . Human development report:. Institute of Economic and Social Research (AIP). United Nations Program for Development. in: URL: http://mirror.undp. org/angola/LinkRtf/nhdr2004 cap2.pdf Accessed on 10th November 2015 .

17. WHO. Basic Laboratory Methods in Medical Parasitology. World Health Organization; 1991.

18. Padua M. Clinical Pathology Technicians (Volume III), Cytology Hematology, 1st ed, Loures edition: Lusociências - Technical and Scientific,; 2011.

19. Sousa-Figueiredo, Gamboa D, Peter JM, JC et al. Epidemiology of malaria, schistosomiasis, geohelminths, anemia and malnutrition in the context of a demographic surveillance system in northern Angola. PLoS One 2012; 7(4):e33189.

20. Xavier RM, Miguel DJ Souza CFM, et al. Laboratory in Clinical Practice, Quick Reference, 2nd ed. Porto Alegre: Oxford University Press; 2010

21. Atouguia J, Almeida AM. Nematodes. Medical Microbiology. Ed Lidel, Lisboa; 2014.

22. Dent AE, Kazura J W. Ascariasis (Ascaris lumbricoides). In: Kliegman Textbook of Pediatrics. 19th ed. Philadelphia: Elsevier Saunders; 2011. 